\title{
Scanning Electron Microscope Evaluation of the Enlarging and Cleansing of the Root Canal with Ultrasonic Vibration
}

\author{
Yoh-ichiroh Soh, Junroh Tahara, Masatoshi Hitaka, \\ Kohzoh Kubota, Kazuo Yasumoto and Hakubu Yamamoto
}

Second Department of Conservative Dentistry (Chief: Prof. Hakubu Yamamoto)

Hideo Miyazaki

Department of Preventive Dentistry (Chief: Prof. Tadamichi Takehara)

Kyushu Dental College, Kitakyushu, Japan

Received March 26, 1987

Key words : Root canal preparation/Root canal wall/SEM

\section{Introduction}

The aims of the enlarging and cleansing of the root canal, a process of endodontic therapy, are the following: to smooth the root canal wall by sweeping away residue inside the root canal, such as bacteria, pulp remnants, necrotic tissues or dentin chips, and possible causes of inflamation, to promote the effects of intra canal medication and facilitate secure root canal filling.

Two different methods are employed for enlarging and cleansing the root canal: the hand instrumentation technique using a reamer and/or a file, and chemical irrigation by means of $\mathrm{NaOCl}, \mathrm{H}_{2} \mathrm{O}_{2}$ and/or EDTA. At present, both techniques are used in the enlarging and cleansing of the root canal. Our series of studies $^{(-5)}$ have, however, demonstrated that these methods are not enough for the sufficient enlarging and cleansing of the apical area of the root canal, which is the most important region in successful root canal treatment.

In recent years, many authors ${ }^{6 \sim 13}$ ) have reported the effects of the application of ultrasonic vibration in endodontics. With the improvement of ultrasonic vibration units, this technique has come to be used for enlarging and cleansing the root canal and for root canal filling. We carried out basic research on the enlarging and cleansing of the root canal with ultrasonic vibration, and evaluated the effects of both hand instrumentation and ultrasonic vibration.

\section{Materials and Methods}

Extracted human maxillary anterior teeth were used in our experiment. Before the experiment reported below, these extracted teeth were put through the following pro- 
cess: cavity preparation was done in the usual way and, after confirming the reach of the \#15 K-type file (Maillefer, Switzerland) to the apical foramen, the working length was measured.

Group 1: five teeth, cleansed with distilled water, reamed and filed from \#15 to \#40 of the K-type file.

Group 2: five other teeth, in which, after reaming and filing by the same procedure as was employed for Group 1, the \#15 K-type file was inserted to a point $2 \mathrm{~mm}$ before the end of the working length and its head was installed in the ultrasonic vibration unit (ENAC Type III, Osada, Japan). It was then activated for a minute under a tap water drip, maintaining purely push-pull action.

In both groups, after the experiment, each tooth crown was cut off from the root using a diamond disk. Each root was sectioned horizontally, into the coronal, middle and apical thirds. A diamond disk was used to cut two deep furrows longitudinally on the labial and lingual surfaces of all the root blocks. Mechanical force was then applied to each root block, fracturing it into two parts - a mesial face and a distal face. After this procedure, each sample block was processed in the usual way ${ }^{1 \sim 5}$ ) and observed by scanning electron microscope (JSM-T300, JEOL, Japan).

\section{Results}

Group 1: The photograph of the root canal wall in the coronal area of the root (magnification $\times 75$ ) showed, in its left upper part, the presence of gross masses containing pulp tissue, dentin chips, etc. The area around this mass was covered with a smeared, platelike layer, and openings to the dentinal tubule were not observed (Fig. 1). In the photograph under magnification $\times 2,000$, openings to the dentinal tubule were not observed either, on account of the presence of a thick smeared layer containing pulp tissue, necrotic tissue and dentin chips (Fig. 2). Under a magnification of $\times 75$, the

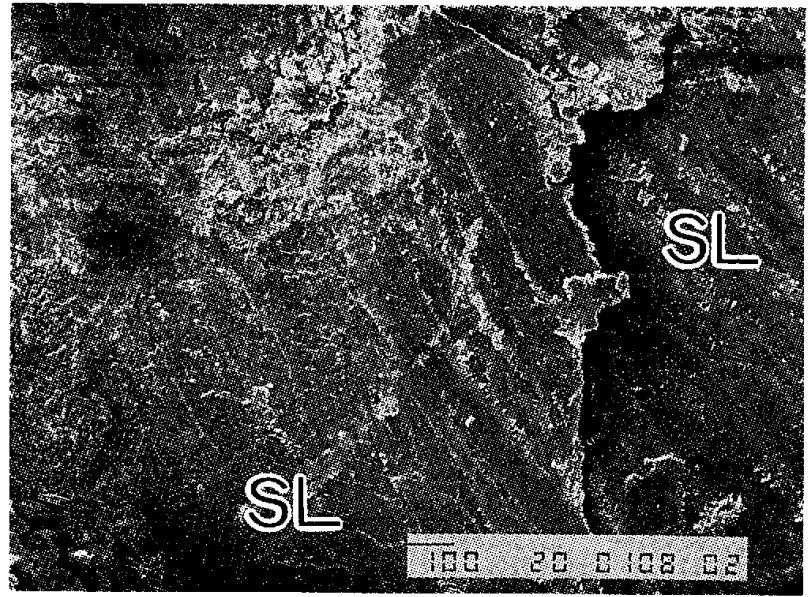

Fig. 1 Conventional hand filing (K-file). The coronal region shows the presence of the smeared layer (SL). (Original magnification $\times 75$ )

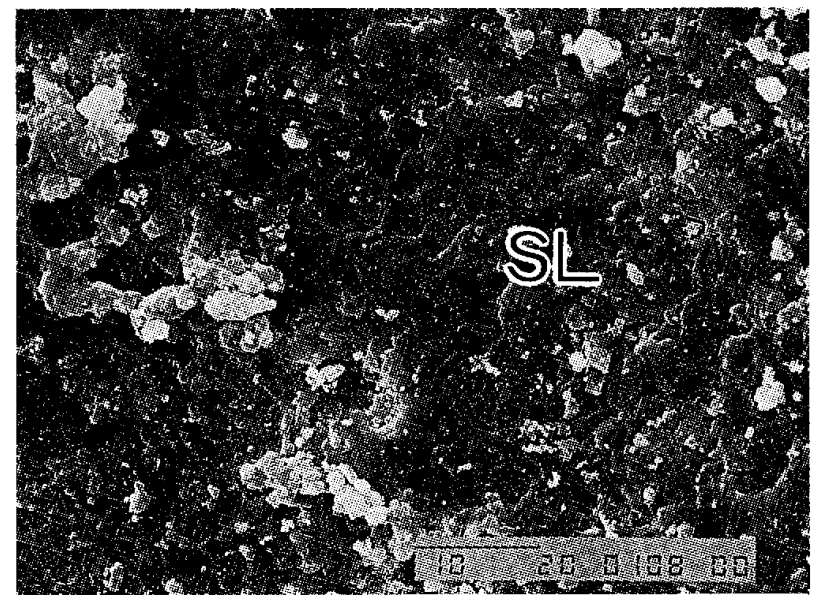

Fig. 2 Conventional hand filing ( $\mathrm{K}$-file). The coronal region shows the presence of the smeared layer (SL). (Original magnification $\times 2000$ ) 
photograph showed a thin membranelike smeared layer, along with small fragments thought to be fragments of a drug, covering the root canal wall in the middle region of the root canal (Fig. 3). Under a magnification of $\times 2,000$, several openings to the dentinal tubule, and a thin membranelike smeared layer containing dentin chips, pulp tissue, etc. of various sizes were observed in the photograph (Fig. 4). Under magnifications of $\times 75$ and $\times 2,000$, various sizes of dentin chips were observed in the photograph, and the openings to the dentinal tubule were obscured with thick smeared layer in the apical area of the root canal (Figs. 5, 6).

Group 2: The photograph, observed under a magnification of $\times 75$, showed the presence of small masses considered to be soft tissues on a part of the wall in the

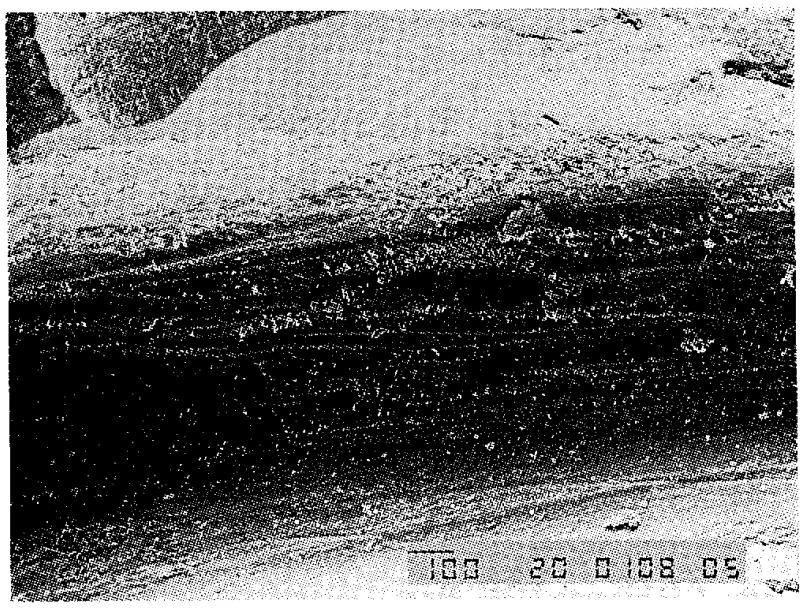

Fig. 3 Conventional hand filing ( $\mathrm{K}$-file). The midroot region is superficially clean. (Original magnification $\times 75$ )

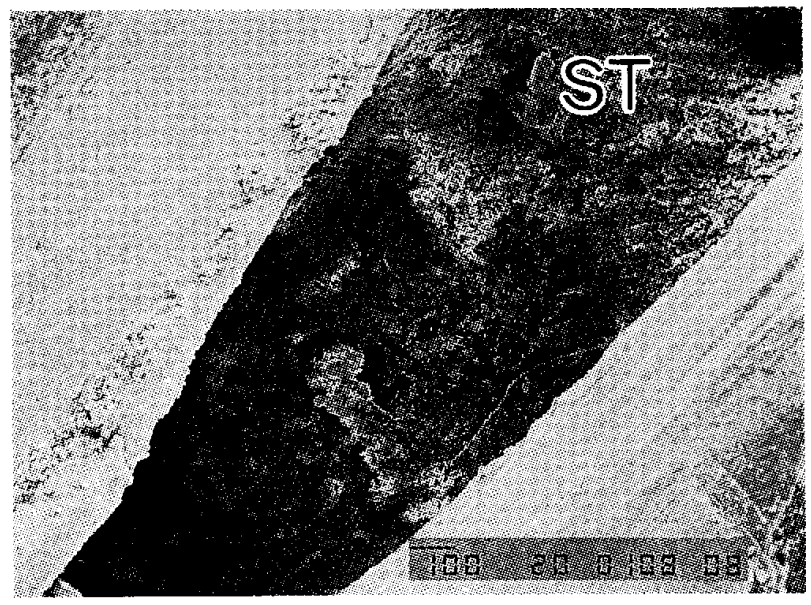

Fig. 5 Conventional hand filing ( $\mathrm{K}$-file). The apical region shows large accumulation of soft tissue (ST) at low power. (Original magnification $\times 75$ )

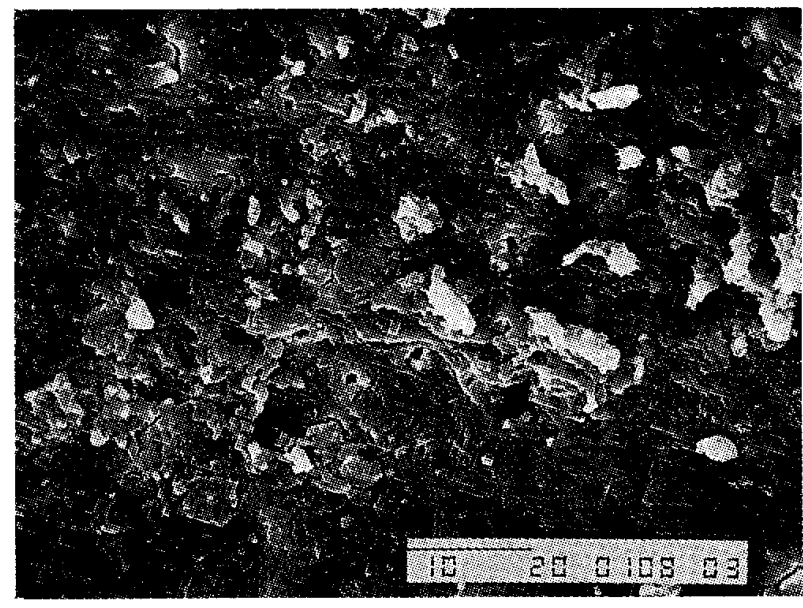

Fig. 4 Conventional hand filing ( $\mathrm{K}$-file). High power view of fig. 3 , showing presence of smeared layer. (Original magnification $\times 2000$ )

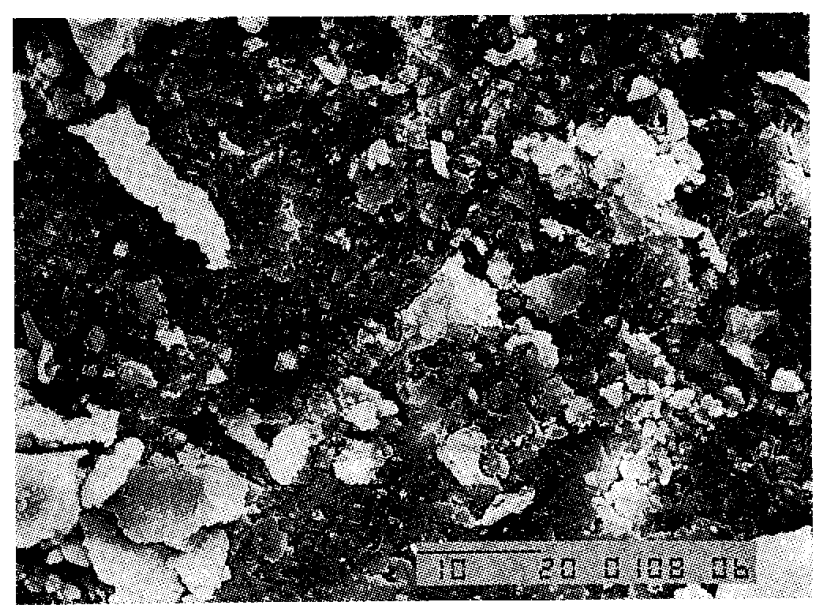

Fig. 6 Conventional hand filing ( $\mathrm{K}$-file). High power view of fig. 5 , the dentin is covered with the smeared layer. (Original magnification $\times 2000$ ) 
coronal area of the root; many traces of grinding by the $\mathrm{K}$-type file with ultrasonic vibration were observed on the entire wall (Fig. 7). Under a magnification of $\times 2,000$, openings to the dentinal tubule were not observed in the photograph, on account of the presence of a smeared layer containing dentin chips of diverse sizes (Fig. 8). In the middle area of the root canal, as observed in the photograph under a magnification of $\times 75$, there were many small particles thought to be dentin chips; the uneven surface manifested traces of grinding due to the K-type file, used with ultrasonics (Fig. 9). Under a magnification of $\times 2,000$, scattered fragments of the smeared layer, with irregular forms and without structure, were observed and the openings to the dentinal

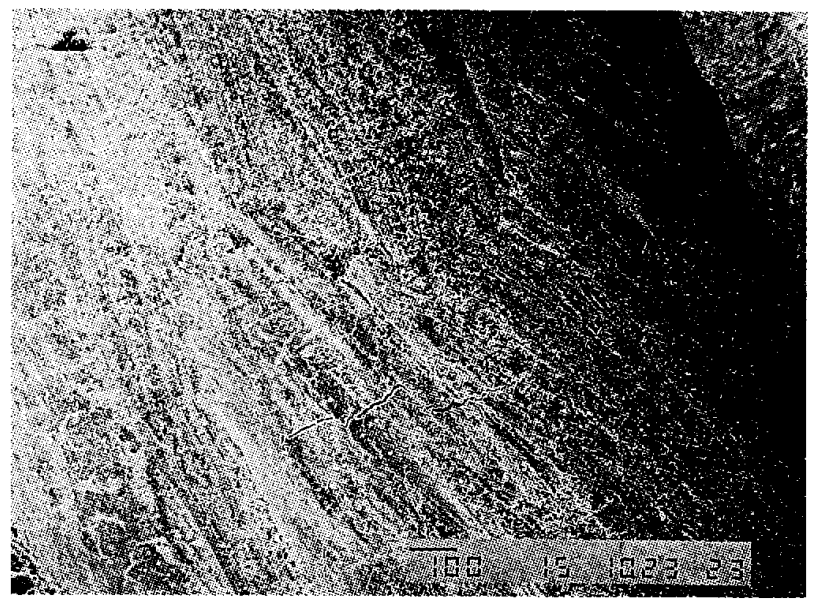

Fig. 7 Ultrasonic vibration. Coronal region is superficially free of debris at low power. (Original magnification $\times 75$ )

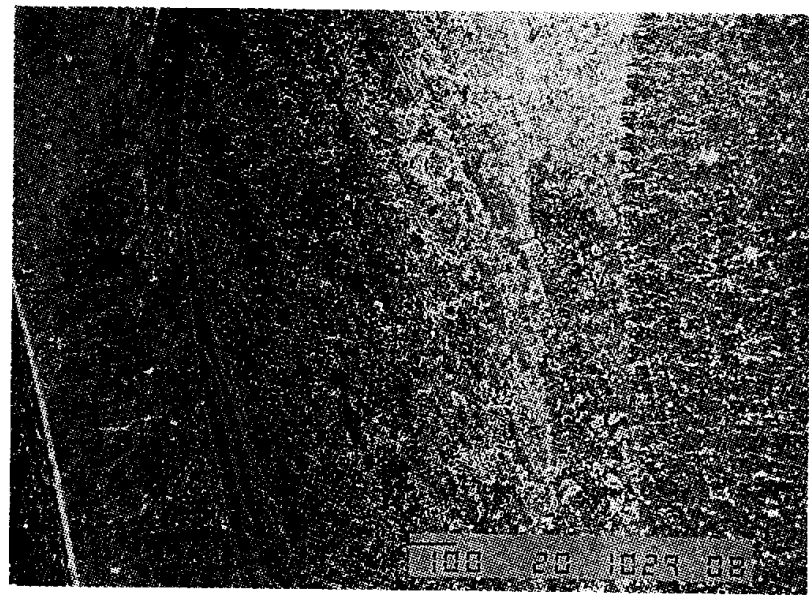

Fig. 9 Ultrasonic vibration. Midroot region is superficially clean. (Original magnification $\times 75$ )

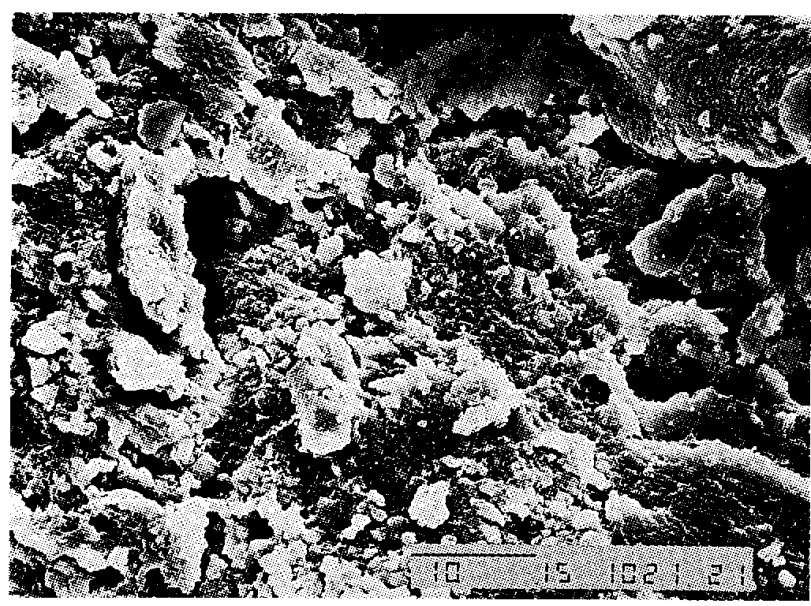

Fig. 8 Ultrasonic vibration. High power view of the coronal region showing smeared layer. (Original magnification $\times 2000$ )

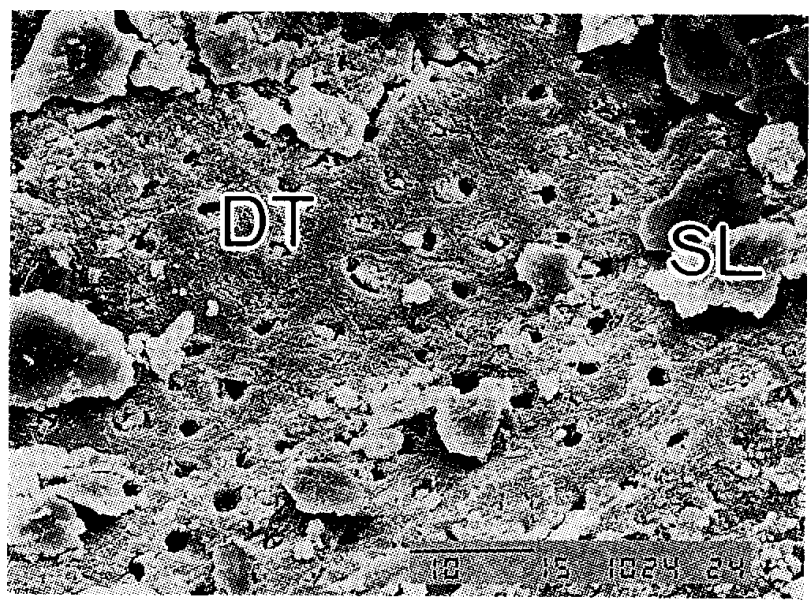

Fig. 10 Ultrasonic vibration. High power view of the midroot region showing patent dentinal tubules (DT), but the presence of the smeared layer. $($ SL) . (Original magnification $\times 2000$ ) 


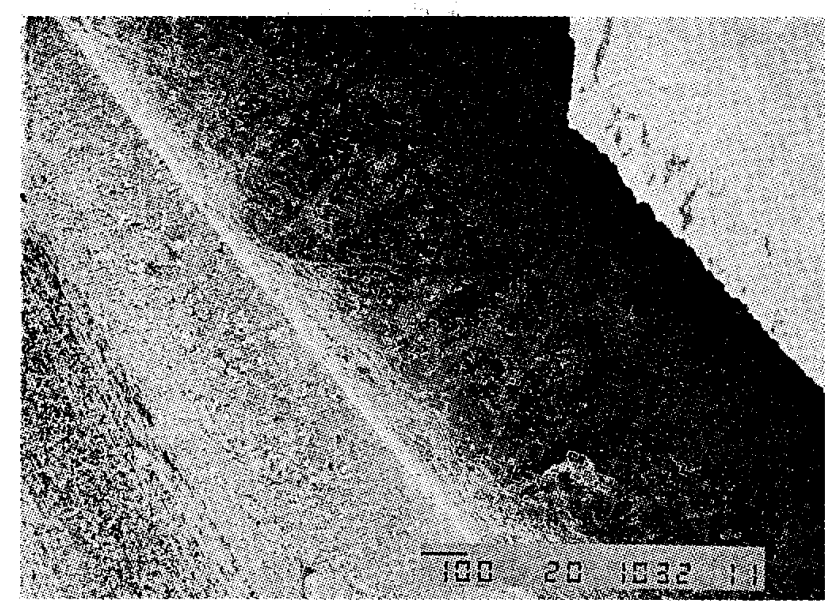

Fig. 11 Ultrasonic vibration. The apical region is, also, superficially clean. Original magnification $\times 75$ )

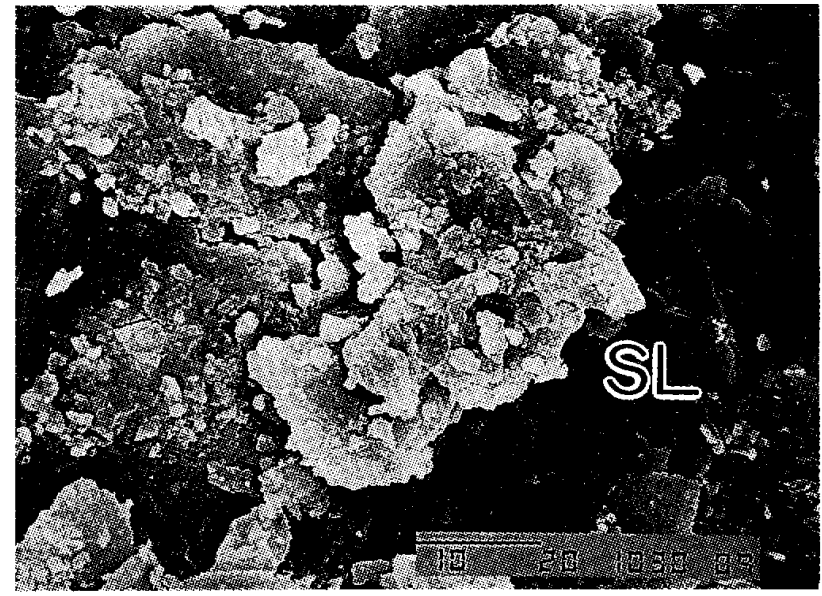

Fig. 12 Ultrasonic vibration. High power view of the apical region shows the presence of the smeared layer (SL). (Original magnification $\times 2000$ )

tubule were obscured by a thin smeared layer (Fig. 10). In the apical area of the root canal, observed in the photograph under a magnification of $\times 75$, the root canal wall was scattered with many small masses of pulp remnants, dentin chips, etc.; the entire region of the wall was covered with a smeared layer (Fig. 11). Observed in the middle part of the photograph under a magnification of $\times 2,000$, was a large mass containing pulp remnants, dentin chips, etc.; the region under this mass was covered by a structureless smeared layer, and openings to the dentinal tubule were not observed (Fig. 12).

\section{Discussion}

The enlarging and cleansing of the root canal is a key requirement in successful root canal preparation. It is therefore important to perform the enlarging and cleansing of the root canal in an appropriate way. As only hand instrumentation is not enough for this, it is advisable to combine hand instrumentation with the use of various agents for canal irrigation. It is, however, difficult to make the agents reach every nook of the root canal in its apical area by means of the syringes widely used in clinics for the irrigation of the root canal, since the root canal is narrow and complex in its apical area. In recent years, the use of ultrasonic vibration in root canal irrigation has been investigated.

In the experiment, the conventional hand instrumentation technique was employed in the treatment of Group 1. A gross mass containing bacteria, pulp remnants, necrotic tissues and dentin chips was observed but the presence of the dentinal tubule was obscured by a thick smeared layer. Gutiérrez, et al. ${ }^{14}$ reported that, in many cases, after enlarging the root canal using a reamer and/or a file...the instruments left a pathway through the geometric center of the root canal, cutting off only a minute part of the dentin walls. Davis, et al. ${ }^{15}$ ) reported that after the same procedure ... standard 
instrumentation techniques tend to leave a considerable portion of the canal wall untouched. Miki, et al. ${ }^{16)}$ reported similar findings as well. Thus, a satisfactory modeling of the root canal walls is not possible using only conventional hand instrumentation techniques. This is due to the internal anatomy of the root canal, that is, its irregular shape, the presence of accessory canals and buccal, lingual or mixed prolongations ${ }^{14)}$. Another possibility is that, as is shown among our findings (Fig. 8), after the root canal was enlarged and cleansed, the root canal walls in the apical area were smeared with pulp remnants, dentin chips, etc. by the process of filing.

After the treatment of the root canal in Group 2, a photograph under a magnification of $\times 75$ did not show residua of pulp remnants; better results were obtained than in Group 1. This is probably due to the delicate grinding effects of ultrasonic vibration, and the cavitation effects and mixing action of a tap water drip. Moriya ${ }^{17}$ ), who conducted an experiment similar to ours, reported that the smeared layer was completely removed. Cymerman, et al. ${ }^{18)}$ Shimada, et al. ${ }^{19)}$ and Kusano, et al. ${ }^{20}$ on the other hand, admitted that there was no difference in the appearance of the root canal walls when the effects of ultrasonic vibration and hand instrumentation techniques were compared. Moriya ${ }^{17}$ ), in his study, has not indicated which part his observations are of; all his observations reported are of the photographs under high magnification. Therefore, considering the complexity of the internal anatomy of the root canals, the conclusion of Moriya $^{17)}$ would better be regarded as that on the action of ultrasonics on the root canal wall. Cymerman, et al. ${ }^{18)}$ and other authors ${ }^{19,20)}$ reported observations on the whole region of the root canal wall from photographs under low magnification.

In our experiment with Group 2, using ultrasonic vibration as well, the complete removal of the smeared layer was not observed, although the condition of the root canal wall achieved was better than in the experiment with the hand instrumentation technique. Above all, a smeared layer was observed on the root canal wall in the apical area, which is the part most crucial for successful root canal treatment. Upon an observation of this area, there was no difference between the effects of the two techniques. Our observations are identical to those of Cymerman, et al.18) and others ${ }^{19,20)}$. We are now going to search for effective methods of removing the smeared layer in the apical area of the root canal wall.

\section{Summary}

Experiments were conducted on ten human maxillary anterior teeth, extracted for the purpose of comparing the effects of hand instrumentation, and those of a combination of this technique with ultrasonic vibration, in the enlargement and cleansing of the root canal. The results obtained by these two diverse procedures examined by SEM. In the enlargement and cleansing of the root canal wall conducted by conventional hand instrumentation, the openings to the dentinal tubule were obscured by a thick smeared layer for all of the three regions, the coronal, middle and apical regions, of the root canal 
walls. In the observation of the root canal wall under low magnification, better results were observed with a combination of the techniques than with hand instrumentation only. When observations were made on the root canal walls in the apical area, however, no difference was observed between the two procedures; the apical area of root canal walls, which was the part most crucial in the prognosis of root canal treatment, was covered with a smeared layer even in the experiment using a combination of the techniques. These results indicate the necessity of the development of effective methods for removing the smeared layer from the region treated.

\section{References}

1) Soh, Y., Tahara, J., Hitaka, M., Kubota, K., Yasumoto, K. and Yamamoto, H. : Scanning electron microscopic study of root canal walls after root canal preparation and irrigation (part 1).J. Kyushu Dent. Soc. 39:847-852, 1985, (in Japanese).

2) Soh, Y., Tahara, J., Hitaka, M., Kubota, K., and Yamamoto, H. : Scanning electron microscopic study of root canal walls after root canal preparation and irrigation (part 2).J. Kyushu Dent. Soc. 40:677-685, 1986, (in Japanese) .

3) Soh, Y., Tahara, J., Hitaka, M. and Yamamoto, H. : Scanning electron microscopic study of root canal walls after root canal preparation and irrigation (part 3). J. Kyushu Dent. Soc. $40: 1413-1421,1986$, (in Japanese).

4 Soh, Y., Tahara, J., Hitaka, M., Yamamoto, H. and Miyazaki, H. : Scanning electron microscopic study of root canal walls after root canal preparation and irrigation (part 4$). J$. Kyushu Dent. Soc. 41:406-413, 1987, (in Japanese).

5) Soh, Y., Tahara, J., Hitaka, M., Kubota, K., Yasumoto, K., Yamamoto, H., Kuroki, K. and Ohsumi, T. : A scanning electron microscopic study of the root canal inner walls after use of various canal irrigation agents. J. Kyushu Dent. Soc. 41:525-532, 1987, (in Japanese).

6) Martin, H., Cunningham, W.T., Norris, J.P. and Cotton, W.R. : Ultrasonic versus hand filing of dentin: A quantitative study. Oral Surg. $49: 79-81,1980$.

7) Martin, H. and Cunningham, W.T. : The effect of endosonic and hand manipulation on the amount of root canal material extruded. Oral Surg. 53:611-613, 1982.

8 ) Cunningham, W.T. and Martin, H. : A scanning electron microscope evaluation of root canal debridement with the endosonic ultrasonic synergistic system. Oral Surg. 53:527-531, 1982.

9) Kusano, Y., Odagawa, H., Murakami, N. and Ishibashi, M. : Efficiency of cleansing the root canal by the use of ultrasonic vibration: Part 2 (Scanning electron microscopic observation of root canal walls). Japan. J. Conserv. Dent. 29:953-959, 1986, (in Japanese).

10) Cunningham, W.T., Martin, H. and Forrest, W.R. : Evaluation of root canal debridement by the endosonic ultrasonic synergistic system. Oral Surg. $53: 401-404,1982$.

11) Cunningham, W.T., Martin, H., Pelleu, Jr., G.B. and Stoops, D.E. : A comparison of antimicrobial effectiveness of endosonic and hand root canal therapy. Oral Surg. $54: 238-$ $241,1982$.

12) Cameron, J.A. : The use of ultrasonics in the removal of the smear layer: A scanning electron microscope study. J. Endod. $9: 289-292,1983$. 
13) Pedicord, D., ElDeeb, M.E. and Messer, H.H. : Hand versus ultrasonic instrumentation: Its effect on canal shape and instrumentation time. J. Endod. $12: 375-381,1986$.

14) Gutiérrez, J.H. and Garcia, J. : Microscopic and macroscopic investigation on results of mechanical preparation of root canals. Oral Surg. $25: 108-116,1968$.

15) Davis, S.R., Brayton, S.M. and Goldman, M. : The morphology of the prepared root canal: A study utilizing injectable silicone. Oral Surg. $34: 642-648,1972$.

16) Miki, Y., Takiguchi, Y., Omoto, G., Kajiwara, T., Yaoi, M. and Uemura, M. : Scanning electron microscopic examination of the root canal wall after preparation. Japan. J. Conserv. Dent. 21:427-437, 1978, (in Japanese).

17) Moriya, K. : Fundamental study of root canal preparation by ultrasonic system. Japan. J. Conserv. Dent. $27: 333-360$. 1984, (in Japanese).

18) Cymerman, J.J., Jerome, L.A. and Moodnik, R.M. : A scanning electron microscope study comparing the efficacy of hand instrumentation with ultrasonic instrumentation of the root canal. J. Endod. $9: 327-331,1983$.

19) Shimada, M., Okada, R., Tamazawa, K. and Horiuchi, H. : Effects of ultrasonic vibration applied to instruments on efficiency of canal preparation. Japan. J. Conserv. Dent. 27 : $632-641$, 1984, (in Japanese).

20) Kusano, Y., Saitoh, H., Murakami, N., Suzuki, T. and Ishibashi, M. : Efficiency of enlarging the root canal and the cleansing effect by ultrasonic vibration. Japan. J. Conserv. Dent. $28: 973-979,1985$, (in Japanese). 


\title{
超音波振動による根管㹡大，清掃法の走査電顕的評価
}

\author{
九州崡科大学保存学第 2 講座（主任：山本博武教授） \\ 等洋一郎・田 原 準 郎・日 高 理 智 \\ 久保田 浩 三・安 元 和 雄 - 山本 博 武 \\ 九州菌科大学口腔衛生学講座（主任：竹原直道教授）
}

宮崎 秀 大

抜去されたヒトの上頢前歯10歯を用い, 手用器械によ るリーミングとファイリングの場合と，それに超音波振 動を併用した場合の根管壁の拡大, 清掃効果を知る目的 で実験を行なった。これら，2 通りの方法で得られた試 料を走查電顕で観察した結果, 手用器械( $\mathrm{K}$ ファイル) により拡大, 清掃された根管壁は, 根管の歯冠側, 中央 部, 根尖部ともかなり厚い smeared layer に覆われて おり，象牙細管の開口部は観察できなかった．超音波振 動により拡大, 清掃された根管壁は，根管中央部では部 分的に smeared layer が除去され象牙細管の開口部が
みられたが，歯冠側と根尖部では観察されなかった。手 用器械だけの場合と超音波振動を㐼用した場合で根管壁 の状態を比較すると，根管壁全面についてみるならば， 超音波振動を併用したときの方が良好な状態であった。 しかしながら，根管治療や根管充填の成否にとって重要 な部位である根尖部のその状態は，乙の雨手法には特に 異なる所見は認められなかった。乙のととは，根管拡大 および清掃の術式に新たな手法の考案が必要であること を示唆している。 